\title{
Spatial and temporal trends in condition of Atlantic cod Gadus morhua on the Icelandic shelf
}

\author{
Heidi Pardoe $^{1,2, *}$, Gudmundur Thórdarson ${ }^{1}$, Gudrun Marteinsdóttir ${ }^{2}$ \\ ${ }^{1}$ Marine Research Institute, Skúlagata 4, PO Box 1390, 121 Reykjavik, Iceland \\ ${ }^{2}$ Institute of Biology, University of Iceland, Sturlugata 7, 101 Reykjavik, Iceland
}

\begin{abstract}
Interannual (1993 to 2006), spatial and bathymetric trends in the hepatosomatic index $(\mathrm{H})$ and relative body condition index $(\mathrm{Kr})$ of Atlantic cod Gadus morhua in Icelandic waters were investigated from data collected during annual spring (March) groundfish surveys. Individual stomach content data were analysed to assess the relationship between condition and consumption of capelin Mallotus villosus. Liver condition was found to vary with region and depth, tending to be highest in deeper water and in the northern and eastern regions; where temperatures were relatively cold and capelin consumption relatively high. A continuous decline in condition of cod in waters off the east coast was observed throughout the study period. Mature cod were found to be in significantly better condition than immature cod of the same age, and mature females were in better condition than mature males. Different patterns emerged from the 2 condition indices; little variation in $\mathrm{Kr}$ was observed whereas $\mathrm{H}$ was found to be a dynamic index of condition, suggesting that these metrics are not equivalent measures of cod bioenergetic condition.
\end{abstract}

KEY WORDS: Cod - Iceland - Liver condition - Body condition - Spatial variation · Bathymetric variation $\cdot$ Capelin $\cdot$ Stomach content

Resale or republication not permitted without written consent of the publisher

\section{INTRODUCTION}

Fish condition is influenced by the combined effects of physiological and environmental factors (Cui \& Wootton 1988) and follows seasonal and annual cycles in cod (Lambert \& Dutil 1997a, Schwalme \& Chouinard 1999, Lloret \& Rätz 2000, Yaragina \& Marshall 2000), reflecting patterns of energy accumulation and depletion during periods of intense feeding, maturation, reproduction, migration and over-wintering (Eliassen \& Vahl 1982a,b, Holdway \& Beamish 1984, Lambert \& Dutil 1997a). Simple metrics of condition, such as the commonly utilised Fulton's $\mathrm{K}$ and hepatosomatic index $(\mathrm{H})$, are based only on length and weight data, but have been found to be reliable indicators of biochemical composition and energy reserves (those stored in muscle proteins and liver lipids respectively) of Atlantic cod (Lambert \& Dutil 1997b).

Condition has been shown to influence or be correlated with most life history parameters, notably those linked with energetic processes, and has the potential to provide important information about the productivity and reproductive potential of a stock. In Atlantic cod Gadus morhua, condition is related to fecundity, fertilisation success, egg size, larval quality and viability, atresia and the probability of skipped spawning (e.g. Kjesbu et al. 1991, Marteinsdóttir \& Steinarsson 1998, Rakitin et al. 1999, Lambert \& Dutil 2000, Rideout et al. 2000, Marteinsdóttir \& Begg 2002, Rose \& O'Driscoll 2002, Yoneda \& Wright 2004, 2005a). However, other studies (e.g. McIntyre \& Hutchings 2003, Koops et al. 2004) have found contrasting evidence for such relationships. Condition was found to influence recruitment in the Northeast Arctic cod stock (Marshall et al. 1999, 2000), the risk of post-spawning mortality in Atlantic cod (Lambert \& Dutil 2000) and the probability of being mature in Atlantic cod (Marteinsdóttir \& Begg 2002, Dutil et al. 2006), walleye Stizostedion vitreum (Henderson \& Morgan 2002) and female American plaice Hippoglossoides platessoides (Mor- 
gan 2004). Furthermore, positive correlations between growth rate and condition have been detected (Holdway \& Beamish 1984, Björnsson 2002, Rätz \& Lloret 2003), and poor condition may result in increased rates of natural mortality through greater vulnerability to disease, predation and reduced capability to catch mobile prey (Dutil \& Lambert 2000, Dutil et al. 2006).

Features of the environment which influence physiological condition, such as temperature and food supply (Krohn et al. 1997), are likely to vary within the geographic area inhabited by a stock. The hydrography of the waters surrounding Iceland has been described by several authors (see Vilhjálmsson 2002 for an overview). The system is characterised by several currents, linked to bottom topography, which generate spatial and temporal differences in the water masses around Iceland. The south and west coasts are influenced by Atlantic water of relatively high temperature, salinity and stability, in contrast to the northern and eastern areas, where polar water transported by the more variable East Greenland and East Icelandic currents predominates (Vilhjálmsson 2002). Capelin Mallotus villosus is the most important prey item of Icelandic cod (Magnússon \& Pálsson 1989, 1991), and its migrations and distribution on the Icelandic shelf and in the Iceland Sea are closely linked to this system of ocean currents, and are highly sensitive to environmental fluctuations (Vilhjálmsson 2002).

Traditionally, biological sampling schemes for stock assessments have, in addition to catch and effort data, only required information on length and age (Sparre \& Venema 1998). The additional effort and resources required to obtain weight data means that the information necessary to systematically or even accurately estimate trends in condition using established simple metrics is lacking for most fish stocks, particularly for long-term studies. In Iceland, such data for cod have been routinely collected during spring groundfish surveys. Here we analyse these data to produce a comprehensive report on the potential variation in condition that has existed within the Icelandic cod stock during the period 1993 to 2006, and to assess the influence of water temperature, bathymetry and feeding (by analysis of stomach content data) on the emergent patterns. An important part of the study was to examine the effect of age, sex and maturity status on $\mathrm{H}$ and the relative body condition index (Kr).

\section{MATERIALS AND METHODS}

Data were obtained from the annual (1993 to 2006) spring groundfish survey conducted by the Marine Research Institute, Iceland. The surveys were conducted in March, overlapping with the beginning of the spawning season for cod (Pálsson et al. 1989). More than 550 fixed-location stations, covering the area of the continental shelf of Iceland occupied by cod, were sampled each year using a bottom trawl with $40 \mathrm{~mm}$ mesh size in the codend (our Fig. 1; Pálsson et al. 1989). At most stations a minimum of 5 and a maximum of 25 fish were sampled randomly, for which total length (L) was measured to the nearest $1 \mathrm{~cm}$, and body, gutted (GW) and liver weights (LW) were determined to the nearest $1 \mathrm{~g}$. Otoliths were collected for identification of individual age, sex was recorded and maturity stage (1: immature, 2: ripening, 3: spawning, 4: spent) was determined macroscopically according to the stages defined in Powles (1958). In the present study, we chose to focus on those age classes where both immature and mature cod are represented. Therefore data for immature $(\mathrm{n}=9907)$ and mature $\operatorname{cod}(\mathrm{n}=7354)$ aged 5 yr (5I, 5M respectively) and 6 yr (6I, $6 \mathrm{M}$ respectively) were selected.

The data were divided geographically into 4 regions; south (S), west (W), north (N) and east (E) (Fig. 1) based on hydrographical and ecological differences, as well as the approximate location of the 2 frontal zones: west of Iceland's northwest peninsula (between regions W and $\mathrm{N}$ ) and in the southeast (between regions $\mathrm{E}$ and $\mathrm{S}$ ). Tagging studies (Pálsson \& Thorsteinsson 2003) have revealed at least 2 groups of Icelandic cod based on their foraging strategies: those which almost exclusively inhabit shelf waters above $200 \mathrm{~m}$, and deepwater cod which spend variable periods of time outside of the spawning season in deeper, cooler waters and increase their vertical movement. Therefore, the data were separated at the $200 \mathrm{~m}$ depth contour and classified as either shallow or deep. Sample sizes by age, maturity, region and depth are provided in Appendix 1.

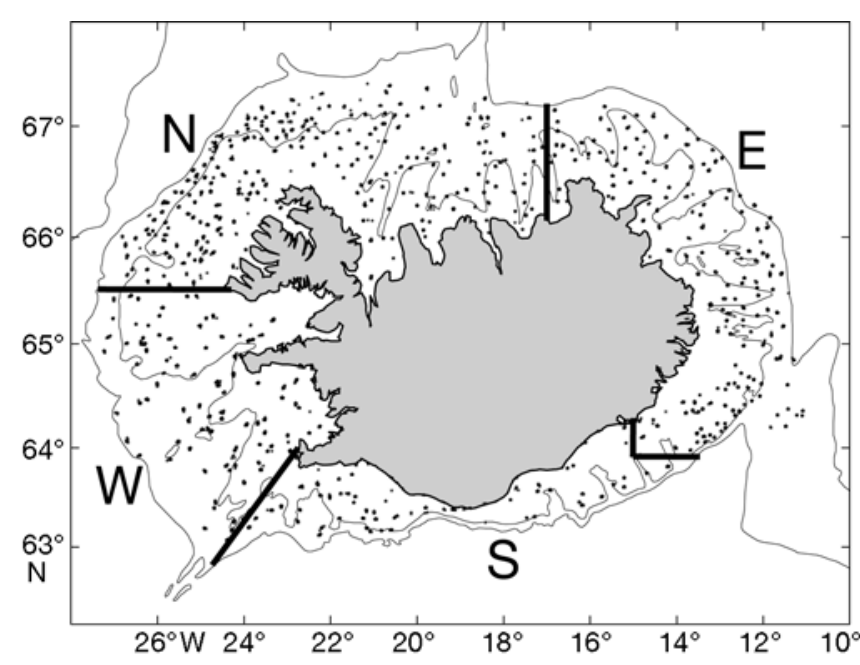

Fig. 1. Station locations of Icelandic spring groundfish surveys (1993 to 2006) for 4 statistical regions: W, N, E and S. Marked are the 200 and $500 \mathrm{~m}$ depth contours 
Condition. Trends in condition were investigated using $\mathrm{H}$ and $\mathrm{Kr}$ (Le Cren 1951), calculated as:

$$
\begin{aligned}
& \mathrm{H}=100\left(\frac{\mathrm{LW}}{\mathrm{GW}}\right) \\
& \mathrm{Kr}=\left(\frac{\mathrm{GW}}{\mathrm{GW}_{\text {pred }}}\right)
\end{aligned}
$$

where $\mathrm{GW}_{\text {pred }}$ is the predicted GW from a length/weight relationship of the form:

$$
\mathrm{GW}=\exp (\alpha+\beta \log \mathrm{L})
$$

where GW and L are measurements from individual cod sampled during the period 1993 to 2006. Rather than the custom linear regression on log-transformed length/weight data, the relationship was estimated using a generalised linear model (GLM) with a log link function and gamma distribution, as GLMs avoid the use of correction factors when backtransforming. The gamma distribution was chosen partly because of increasing variation in the data with length (Gudmundsdóttir \& Steinarsson 1997, Begg \& Marteinsdóttir 2003). A single length/weight relationship (Eq. 3) was estimated for the whole dataset so that $\mathrm{Kr}$ would be comparable across ages, sexes, maturity, regions and years. Cod of length $>90 \mathrm{~cm}(\mathrm{n}=179)$ were excluded from the analyses due to their disproportionate increase in weight (Begg \& Marteinsdóttir 2003), resulting in a poor fit of the estimated length/weight relationship to these large individuals. The condition indices were calculated using GW rather than total weight to ensure a more accurate assessment of trends in condition as feeding intensity and gonad maturation can vary significantly between individuals, locations and years (Lambert \& Dutil 1997a).

We did not use the more familiar Fulton's K as a metric of body condition as it showed an increasing trend with length, and more importantly, the assumption of isometric growth $\left(\mathrm{b}^{3}\right.$ in the formula $\left.\mathrm{K}=\mathrm{W} / \mathrm{L}^{3}\right)$ was not satisfied despite values for slopes of L/GW relationships in the range 2.95 to 3.13 (t-test; $\mathrm{H}_{0}$ slope $(b)=3$ : $\mathrm{p}>0.05$ females $5 \mathrm{M}$ and $6 \mathrm{M}, \mathrm{p}<0.055 \mathrm{I}, 6 \mathrm{I}$, males $5 \mathrm{M}$ and $6 \mathrm{M})$. To test for dependency of the chosen condition indices on size, linear regressions with length were performed. For $\mathrm{H}$, the regressions were significant $(\mathrm{p}<0.001)$ for 5I $(F=44.67,6655 \mathrm{df}), 6 \mathrm{I}(F=110.6$, $3248 \mathrm{df}), 5 \mathrm{M}(F=94.36,3093 \mathrm{df})$ and $6 \mathrm{M}(F=108.1$, $4257 \mathrm{df}$ ); however, all slopes were $\leq 0.016$, and in fact negative for $5 \mathrm{I}$ and $6 \mathrm{I}$, along with all values of the coefficient of determination being very low $\left(\mathrm{r}^{2}<0.03\right)$. Length-Kr regressions were significant $(\mathrm{p}<0.001)$ for 5I $(F=32.07,6655 \mathrm{df})$ and $6 \mathrm{I}(F=103,3248 \mathrm{df})$ with slopes of 0.0004 and 0.0009 and $\mathrm{r}^{2}$ values of 0.005 and 0.03 respectively, but nonsignificant for $5 \mathrm{M}(F=0.003$, $3093 \mathrm{df}, \mathrm{p}=0.95)$ and $6 \mathrm{M}(F=1.735,4257 \mathrm{df}, \mathrm{p}=0.19)$.
The large amount of data (Appendix 1) and resultant high statistical power likely explains the statistical significance of these otherwise very weak relationships. Consequently, the use of $\mathrm{H}$ and $\mathrm{Kr}$ as metrics of condition for the present study was deemed acceptable.

Stomach content analysis. Cod stomach content data have been collected in Icelandic waters since 1979 (Pálsson \& Björnsson 1993). After 1996, stomachs were removed from most individuals for which otoliths were sampled and therefore we examined data for the period 1996 to 2006. Because capelin is the most important prey item of Icelandic cod (Magnússon \& Pálsson 1989, 1991) and has been estimated to contribute 80 to $90 \%$ by weight to the diet of cod in March (Pálsson 1997), analyses of cod stomach content data were restricted to this prey species.

In accordance with Stefánsson \& Pálsson (1997), empty stomachs were considered separately to the amount of capelin observed in non-empty stomachs. To account for differences in fish size, a fullness index (FI; Schwalme \& Chouinard 1999, Björnsson 2002) was calculated for each non-empty stomach as:

$$
\mathrm{FI}=\left(\frac{\mathrm{W}_{\mathrm{cap}}}{\mathrm{GW}}\right)
$$

where $\mathrm{W}_{\text {cap }}$ is the weight ( $\mathrm{g}$ ) of capelin in the stomach of an individual cod. For the annual analysis of FI, ages 5 and 6 yr were combined in order to increase the number of data points. The proportion of capelin in cod stomachs $\left(\mathrm{P}_{\text {cap }}\right)$ for each region and year was estimated as:

$$
\mathrm{P}_{\text {cap }}=100\left(\frac{\sum_{\mathrm{n}} \mathrm{W}_{\text {cap }}}{\sum_{\mathrm{n}} \mathrm{W}_{\text {prey }}}\right)
$$

where $\mathrm{W}_{\text {prey }}$ is the total stomach content weight $(\mathrm{g})$ and $\mathrm{n}$ is the total number of non-empty stomachs in a given region and year (Yaragina \& Marshall 2000).

Statistical analysis. Individual condition data were square-root transformed as this provided the most successful normalisation, an assumption of ANOVA. For these data, 1-way ANOVAs, followed by Tukey's honestly significant difference (HSD) multiple comparison tests (where applicable), were used to identify differences in $\mathrm{H}$ and $\mathrm{Kr}$ between (1) regions, (2) depth strata, (3) sexes of immature (5I, 6I) and mature $\operatorname{cod}(5 \mathrm{M}, 6 \mathrm{M})$ and (4) maturity status of age 5 and 6 yr cod. Tests were performed separately for the appropriate combinations of age, maturity status, sex and region, on combined data for all years.

In addition, ANOVAs were used to examine the combined influence of depth strata, region, year, biological characteristics and 4 first-order interaction terms on average condition. Another assumption of ANOVA is independence of observations. Intrahaul 
correlation associated with fisheries data is likely to invalidate this to some extent (Stefánsson \& Pálsson 1997 and references therein). In order to help alleviate this problem, and reduce the likelihood of obtaining significant effects due to the large amount of data alone (Appendix 1), mean condition was modelled rather than the individual observations. This data is essentially that presented below (see Figs. 2 \& 3) with the exception that, because of their high similarity, only combined data for immature males and females are shown. The final models were:

$$
\begin{aligned}
& \text { mean } \mathrm{H}=\mu+ \mathrm{M}_{i}+\mathrm{D}_{j}+\mathrm{R}_{k}+\mathrm{S}_{n}+\mathrm{Y}_{p}+\mathrm{A}_{q}+(\mathrm{DR})_{j k}+ \\
&(\mathrm{MR})_{i k}+(\mathrm{RY})_{k p}+(\mathrm{RA})_{k q}
\end{aligned}
$$

mean $\mathrm{Kr}=\mu+\mathrm{D}_{j}+\mathrm{A}_{q}+\mathrm{R}_{k}+\mathrm{S}_{n}+\mathrm{Y}_{p}+\mathrm{M}_{i}+(\mathrm{DR})_{j k}+$

$$
(\mathrm{MR})_{i k}+(\mathrm{RY})_{k p}+(\mathrm{RA})_{k q}
$$

where $\mathrm{H}$ and $\mathrm{Kr}$ are the indices of condition, $\mu$ is the mean effect, $M_{i}$ is the maturity effect, $D_{j}$ is the depth strata effect, $\mathrm{R}_{k}$ is the region effect, $\mathrm{S}_{n}$ is the sex effect, $\mathrm{Y}_{p}$ is the year effect, $\mathrm{A}_{q}$ is the age effect and DR, MR, RY and RA are first-order interactions between the main effects. Temperature was not included in Eqs. (6) and (7) as the combination of depth, region and year can be thought of as a proxy for this environmental characteristic (see Fig. 4). An additional measure of model fit was based on a pseudo-coefficient of determination $\left(\mathrm{pR}^{2}\right)$ which was the fraction of the total 'variation' explained by the model:

$$
\mathrm{pR}^{2}=1-\left[\frac{\text { Residual deviance }}{\text { Null deviance }}\right]
$$

where deviance was analogous to the residual sums of squares (Swartzman et al. 1995). The contribution of each effect to the total $\mathrm{pR}^{2}$ was also calculated.

The relationship between mean annual $\mathrm{P}_{\text {cap }}$ and condition of immature and mature cod (ages 5 and $6 \mathrm{yr}$ combined) in shallow $(<200 \mathrm{~m})$ and deep (>200 m) water by region was examined using linear regression analysis. Prior to 2002, mean weight-at-age of cod aged 5 to $8 \mathrm{yr}$ in the winter was positively related to abundance of adult capelin in the previous summer (Vilhjálmsson 2002). Therefore linear regression analysis was used to determine whether similar relationships between annual mean condition of age 5 and 6 yr cod (in March) and annual adult capelin stock biomass and abundance (in both August of the previous year and January of the same year) exist.

\section{RESULTS}

\section{Interannual variation in condition}

The $\mathrm{H}$ and $\mathrm{Kr}$ time series (1993 to 2006) showed rapid fluctuations which were often synchronous across ages, maturity and sexes (Figs. 2 \& 3). In region W, mean annual $\mathrm{H}$ was relatively stable during 1993 to 2000 with values in the approximate ranges of $2-5$, $4-6$ and $6-8 \%$ for $5 \mathrm{I}$, male $5 \mathrm{M} / 6 \mathrm{M}$ and female $5 \mathrm{M} / 6 \mathrm{M}$ respectively. There was no consistent trend in $\mathrm{Kr}$ during this period. A significant peak in $\mathrm{H}$ and $\mathrm{Kr}$ was observed in region $\mathrm{W}$ in $2001 ; \mathrm{H}$ reached $>6 \%$ and $>10 \%$ for most immature and mature cod respectively. By 2002-2003 condition had returned to values similar to those observed previously, followed by a general improvement in the most recent years. In region $\mathrm{N}$, there was an overall decline in liver condition between 1993 and 1999-2001, despite a peak of variable magnitude in 1996-1997. In the latter part of the time period, an improvement in Kr was seen across most age/maturity groups, whereas $\mathrm{H}$ was more variable and even decreased after an additional peak in 2002-2003. In region $\mathrm{E}$ there was an overall decline in condition from 1993 to 2006. Mean $\mathrm{H}$ of female and male 6M decreased from 13-14 and 9-11\%, respectively, to nearer age-specific average values of 6-8\%, accompanied by comparable declines in the other age/maturity groups (Fig. 2). Fish with $\mathrm{GW}>\mathrm{GW}_{\text {pred }}, \mathrm{GW}=\mathrm{GW}_{\text {pred }}$ or $\mathrm{GW}<\mathrm{GW}_{\text {pred }}$ at a given $\mathrm{L}$ will have a $\mathrm{Kr}>1, \mathrm{Kr}=1$ and $\mathrm{Kr}<1$ respectively. In region $\mathrm{E}$, mean $\mathrm{Kr}$ was most often $>1$ prior to 2001, but values $<1$ were more frequent in the latter part of the time period (Fig. 3). Condition was most variable in region $S$, with the exception of $6 \mathrm{M}$ in shallow waters, for which $\mathrm{H}$ was relatively stable during the time period (excluding the peak in 2002) at approximately $6 \%$ and $8.5 \%$ for males and females respectively. The greater fluctuation in this region may be explained in part by the low sample sizes in some years, particularly for immature cod. This inconsistency in interannual variation across the regions is supported by the significant interactions between region and year in ANOVAs which model mean $\mathrm{H}$ and $\mathrm{Kr}$ as a function of spatial, temporal and biological characteristics (Table 1).

\section{Variation in condition with sex, age and maturity status}

Although condition $(\mathrm{H})$ of immature and mature cod overlapped greatly, $\mathrm{H}$ of mature female and male cod was significantly ( $p<0.05$; Fig. 2 ) higher than that of immature cod for all ages and regions. Moreover, maturity was found to be the most important factor in an ANOVA on modelled averages (Table 1). The effect of maturity on $\mathrm{H}$ was dependent to a small degree on the region in which the cod were located, shown by the significant interaction term (Table 1) and through comparison of, for example, differences in mean $\mathrm{H}$ of immature and mature age 6 yr cod in shallow waters of 
regions $\mathrm{N}$ and $\mathrm{E}$ (Fig. 2). For immature cod, no significant differences in $\mathrm{H}$ or $\mathrm{Kr}$ were detected between the sexes $(p>0.05)$. However, age 5 and 6 yr mature female cod had significantly ( $p<0.001$; Fig. 2) higher $\mathrm{H}$ than mature males of the same age in all regions. This was reflected in the multiple-factor ANOVAs; sex significantly affected mean $\mathrm{H}$ and $\mathrm{Kr}$, although it accounted for a low proportion of the variation relative to the other factors. Age did not significantly explain any of the variation in mean $\mathrm{H}$ (Table 1).

It is important to note that despite the high degree of significance of most individual factors in both ANOVA models, the fraction of variation in mean Kr accounted for by the total model $\left(\mathrm{pR}^{2}=0.39\right)$ was approximately

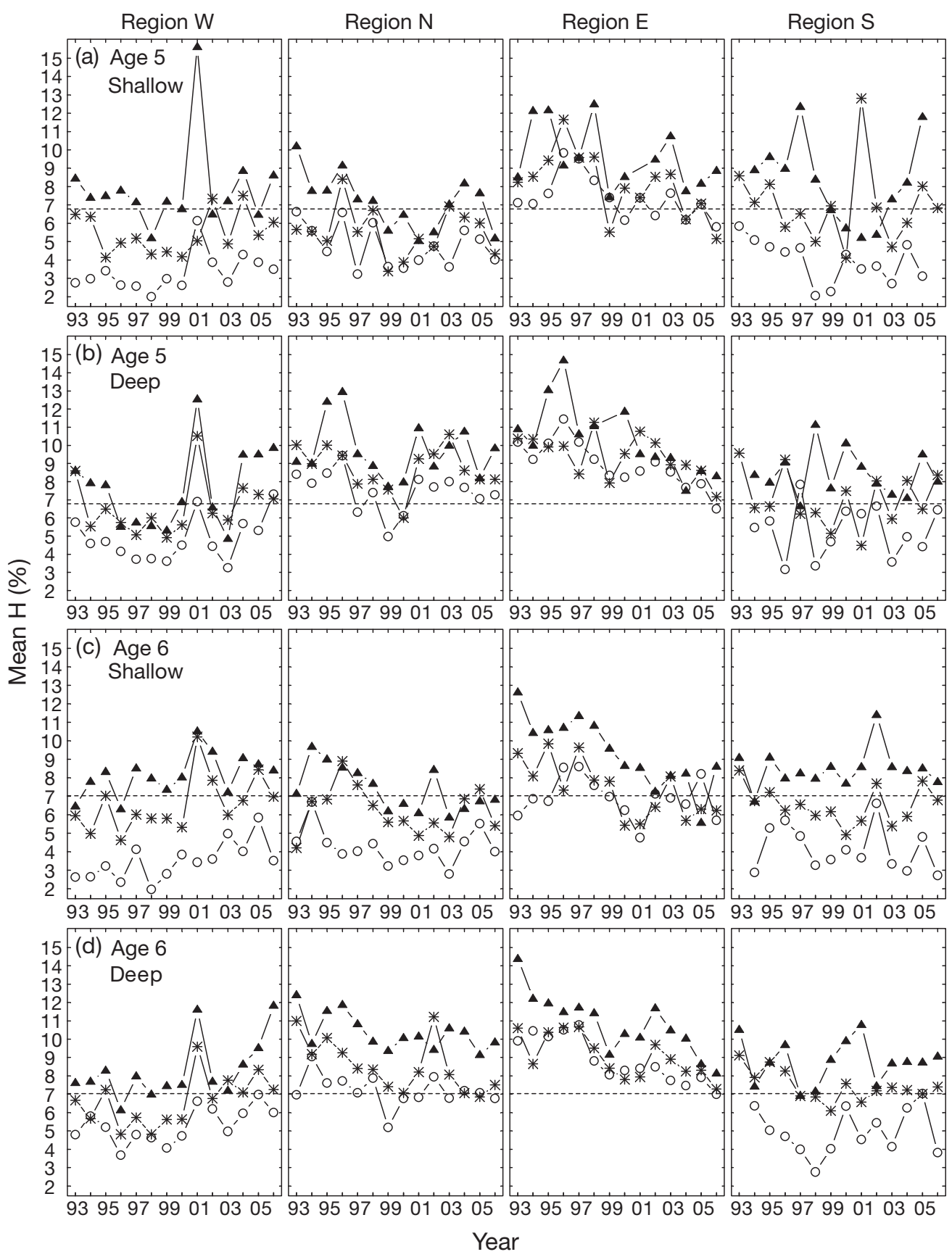

Fig. 2. Gadus morhua. Interannual (1993 to 2006) and spatial variation of mean hepatosomatic index (H, \%) of; age 5 yr immature (O sexes combined) and mature (females $\boldsymbol{\Delta}$ and males $*$ ) cod in (a) shallow ( $<200 \mathrm{~m}$ ) and (b) deep (>200 m) water, and age 6 yr immature (O sexes combined) and mature (females $\boldsymbol{\Delta}$ and males $*$ ) cod in (c) shallow and (d) deep water. The horizontal dashed line shows the overall mean for the age present in each plot 


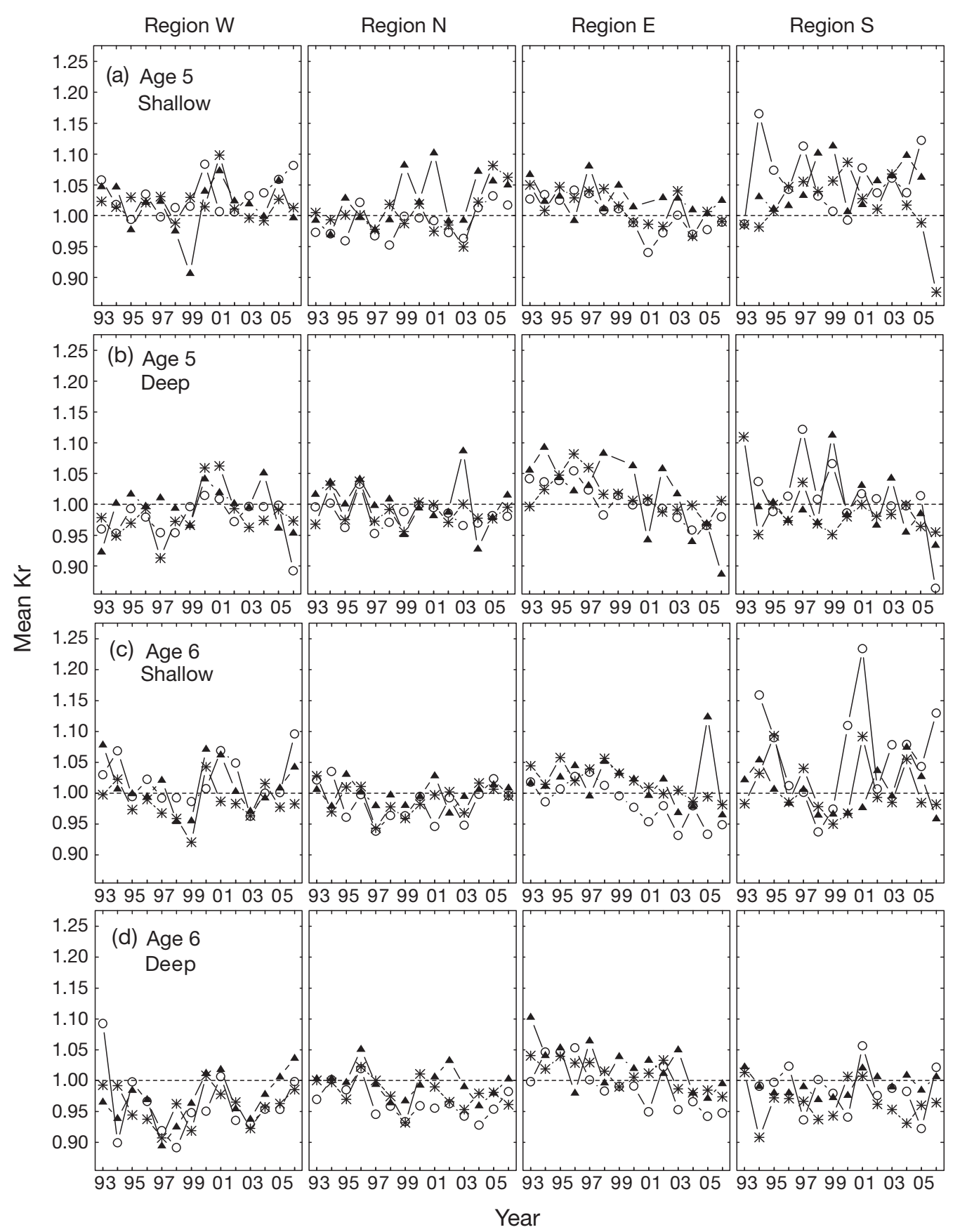

Fig. 3. Gadus morhua. Interannual (1993 to 2006) and spatial variation of mean relative condition factor (Kr) of age 5 yr immature (O sexes combined) and mature (females $\boldsymbol{\Delta}$ and males $*$ ) cod in (a) shallow ( $<200 \mathrm{~m}$ ) and (b) deep ( $>200 \mathrm{~m})$ water, and age 6 yr immature (O sexes combined) and mature (females $\boldsymbol{\Delta}$ and males $*$ ) cod in (c) shallow and (d) deep water. The horizontal line shows $\mathrm{Kr}=1.0$

half that explained in mean $\mathrm{H}\left(\mathrm{pR}^{2}=0.78\right.$, Table 1$)$. In contrast to mean $\mathrm{H}$, maturity did not explain any of the variation in mean $\mathrm{Kr}(\mathrm{p}>0.05$, Table 1). On a regional and age basis, however, $\mathrm{Kr}$ of mature female and male cod in regions $\mathrm{N}$ and $\mathrm{E}$ was significantly $(\mathrm{p}<0.05)$ higher than that of immature cod. In regions $\mathrm{S}$ and $\mathrm{W}$, several comparisons were also significant (region W: $6 \mathrm{I}$ and male $6 \mathrm{M}_{i}$ region S: 5I and male 5M, 6I and female and male $6 \mathrm{M}$ ) but were actually the result of immature cod with higher mean $\mathrm{Kr}$ than mature cod (Fig. 3). Kr was significantly different among the sexes of age $5 \mathrm{yr}$ mature cod in regions $\mathrm{E}$ and $\mathrm{S}(\mathrm{p}<0.05)$ and age $6 \mathrm{yr}$ 
Table 1. Gadus morhua. Multiple-factor ANOVA examining the influence of main effects and first-order interaction terms on average condition (hepatosomatic index, $\mathrm{H}$ and relative condition factor, $\mathrm{Kr}$ ) of Icelandic cod from 1993 to $2006 .{ }^{*} \mathrm{p}<$ $0.05,{ }^{* *} \mathrm{p}<0.0001, \mathrm{~ns}=$ not significant

\begin{tabular}{|lrrrr|}
\hline Source & df & \multicolumn{1}{c}{$\mathrm{SS}$} & $F$ & $\mathrm{pR}^{2}$ \\
\hline $\mathbf{H}$ & & & & \\
Maturity & 1 & 1192.13 & $831.90^{* *}$ & 0.232 \\
Depth & 1 & 513.83 & $358.57^{* *}$ & 0.100 \\
Region & 3 & 1131.98 & $263.31^{* *}$ & 0.221 \\
Sex & 1 & 173.83 & $121.30^{* *}$ & 0.034 \\
Year & 13 & 206.52 & $11.09^{* *}$ & 0.040 \\
Age & 1 & 0.91 & $0.64^{\text {ns }}$ & 0.000 \\
Region $\times$ Depth & 3 & 137.58 & $32.00^{* *}$ & 0.027 \\
Region $\times$ Maturity & 3 & 133.95 & $31.16^{* *}$ & 0.026 \\
Region $\times$ Year & 39 & 472.51 & $8.45^{* *}$ & 0.092 \\
Region $\times$ Age & 3 & 13.89 & $3.23^{* *}$ & 0.003 \\
Residual error & 806 & 1155.01 & & 0.775 \\
Kr & & & & \\
Depth & 1 & 0.15 & $98.83^{* *}$ & 0.074 \\
Age & 1 & 0.06 & $36.57^{* *}$ & 0.028 \\
Region & 3 & 0.08 & $17.85^{* *}$ & 0.040 \\
Sex & 1 & 0.01 & $6.16^{* *}$ & 0.005 \\
Year & 13 & 0.09 & $4.45^{* *}$ & 0.044 \\
Maturity & 1 & 0.00 & $1.35^{\text {ns }}$ & 0.001 \\
Region $\times$ Depth & 3 & 0.10 & $21.70^{* *}$ & 0.049 \\
Region $\times$ Maturity & 3 & 0.08 & $17.89^{* *}$ & 0.040 \\
Region $\times$ Year & 39 & 0.22 & $3.74^{* *}$ & 0.110 \\
Region $\times$ Age & 3 & 0.00 & $0.70^{\text {ns }}$ & 0.002 \\
Residual error & 806 & 1.24 & & 0.393 \\
& & & & \\
\hline
\end{tabular}

mature cod in regions $\mathrm{W}(\mathrm{p}<0.001), \mathrm{N}$ and $\mathrm{S}(\mathrm{p}<0.05)$. Age was a relatively important explanatory factor for the variation in mean $\mathrm{Kr}(\mathrm{p}<0.0001$, Table 1$)$.

\section{Spatial and bathymetric trends in condition}

Spatial variability in $\mathrm{H}$ of Icelandic cod was evident throughout the time period (1993 to 2006) (Fig. 2), although annual variability obscured the differences between regions in some years, an interaction that was also detected statistically (Table 1). Together with maturity and depth, region explained $55 \%$ of the total variation in mean $\mathrm{H}$ (Table 1). Differences in $\mathrm{Kr}$ between regions were more poorly defined (Fig. 3). In general, cod were found to be in best condition in region $\mathrm{E}$ despite the overall decline in condition in this region, with $\mathrm{H}$ and $\mathrm{Kr}$ of both immature and mature cod being above the age-specific average or 1.0 respectively for the majority of years. On the whole, the poorest condition was observed in region W. Differences in $\mathrm{H}$ between the west and east were significant for all age/maturity groups (Tukey's HSD, p < 0.05). Nonsignificant comparisons for $\mathrm{H}$ were those between regions $\mathrm{N}$ and $\mathrm{S}$ for $6 \mathrm{I}, 5 \mathrm{M}$ and $6 \mathrm{M}$ and between regions $\mathrm{W}$ and $\mathrm{S}$ for $6 \mathrm{I}$. This may be due to low numbers of $6 \mathrm{I}$ cod on the main spawning grounds in the south and southwest. However, regions $\mathrm{W}$ and $\mathrm{S}$ did show the most overlap in condition (Fig. 2). Spatial differences in $\mathrm{Kr}$ were also statistically less well defined than $\mathrm{H}_{\text {; }}$ region explained a small fraction of the total variation in mean $\mathrm{Kr}$ (Table 1) and significant region comparisons showed no consistent trend between age/maturity groups. When all ages were combined, however, $\mathrm{Kr}$ of immature fish was significantly different between all regions whereas for mature cod this was only true between regions $\mathrm{W}$ and E (Tukey's HSD, $\mathrm{p}<0.05$ ).

Cod in deep water $(>200 \mathrm{~m})$ had significantly better mean $\mathrm{H}$ than those at depths $<200 \mathrm{~m}$ ( $\mathrm{p}<0.05$; Fig. 2), with the only exception being $6 \mathrm{I}$ in region $\mathrm{S}$, for which few data were available. However, for $\mathrm{Kr}$ the trend was the opposite: mean Kr was significantly higher in shallow water ( $p<0.05$; Fig. 3). Nonsignificant comparisons of mean $\mathrm{Kr}$ between the depth strata were found for 5I in region $\mathrm{N}$ and $6 \mathrm{I}$ in region $\mathrm{E}$. Additionally, depth strata was an important contributing factor to the explanation of total variation in mean $\mathrm{H}$, and to a lesser extent mean $\mathrm{Kr}$ (Table 1). The effect of depth on mean $\mathrm{H}$ and $\mathrm{Kr}$ was somewhat dependent on the region, as shown by the significant interaction terms (Table 1).

\section{Environmental effects}

From measurements made during the survey, annual mean near-bottom temperature was calculated and showed an increasing temporal trend in all regions (Fig. 4). All regions, particularly in the east, were characterised by interannual fluctuations in temperature, which were more or less synchronous between the depth strata. In region $W$, the deep water $(>200 \mathrm{~m})$ was warmer than the shallow water $(<200 \mathrm{~m})$ throughout the study period, whereas in region $E$ the opposite was true. Temperature differences between the depth strata in regions $\mathrm{N}$ and $\mathrm{S}$ were less well defined, with the exception of the most recent years in the north when the deep water remained approximately $1^{\circ} \mathrm{C}$ cooler. In accordance with the known hydrographic conditions of Icelandic waters, mean temperature was highest in region $\mathrm{S}$ and decreased in a clockwise direction. Comparison of the time series of mean condition (Figs. $2 \& 3$ ) and bottom temperature (Fig. 4) did not reveal any obvious overlaps in interannual trends.

Prominent differences in average $\mathrm{P}_{\text {cap }}$ between years and particularly regions were observed. This variation was generally similar between ages 5 and 6 yr; therefore the averaged trends are presented (Fig. 5). In a given region, year and depth stratum, the magnitude of $\mathrm{P}_{\text {cap }}$ was generally quite similar for immature and 


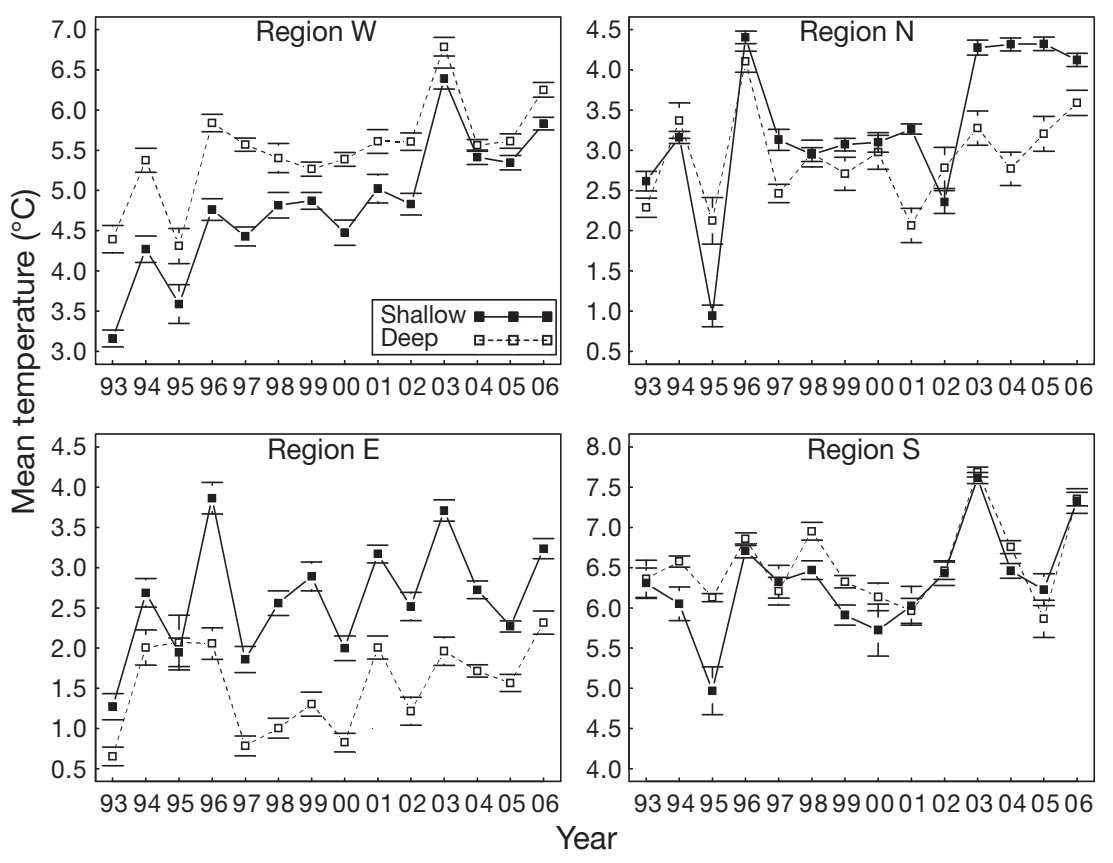

Fig. 4. Annual (1993 to 2006) mean ( $\pm 95 \%$ CI) near-bottom water temperature $\left({ }^{\circ} \mathrm{C}\right.$ ) of 2 depth strata (shallow: $<200 \mathrm{~m}$, deep: $>200 \mathrm{~m}$ ) in 4 statistical regions of the Icelandic shelf. Note different scales on $y$-axes mature cod. Feeding on capelin, at the time of the survey, was highly variable in region $\mathrm{W}$. For immature and mature cod in shallow $(<200 \mathrm{~m})$ water, good capelin feeding years in this region ('good' defined here as $\mathrm{P}_{\text {cap }} \geq 40 \%$ ) were 1997, 2001 and 2002 along with 1996 for mature individuals. In deep (>200 m) water, this can only be said for immature cod in 2001. For the majority of cod in region $\mathrm{W}$, 1998-1999 and 2003-2005 were very poor $\left(\mathrm{P}_{\text {cap }}<10 \%\right)$ capelin feeding years, along with 2006 in deep water. Feeding on capelin, particularly in deep water, was markedly lower in region $S$ than regions $N$ and $E$ in almost all years. In region $\mathrm{S}_{\text {, }} \mathrm{P}_{\text {cap }}$ was consistently $\geq 30 \%$ and $<12 \%$ in shallow and deep water, respectively. In region $\mathrm{N}, \mathrm{P}_{\text {cap }}$ of immature cod in shallow and deep water ranged between $8-100 \%$ and $32-100 \%$, respectively, and $\mathrm{P}_{\text {cap }}$ of mature cod varied between
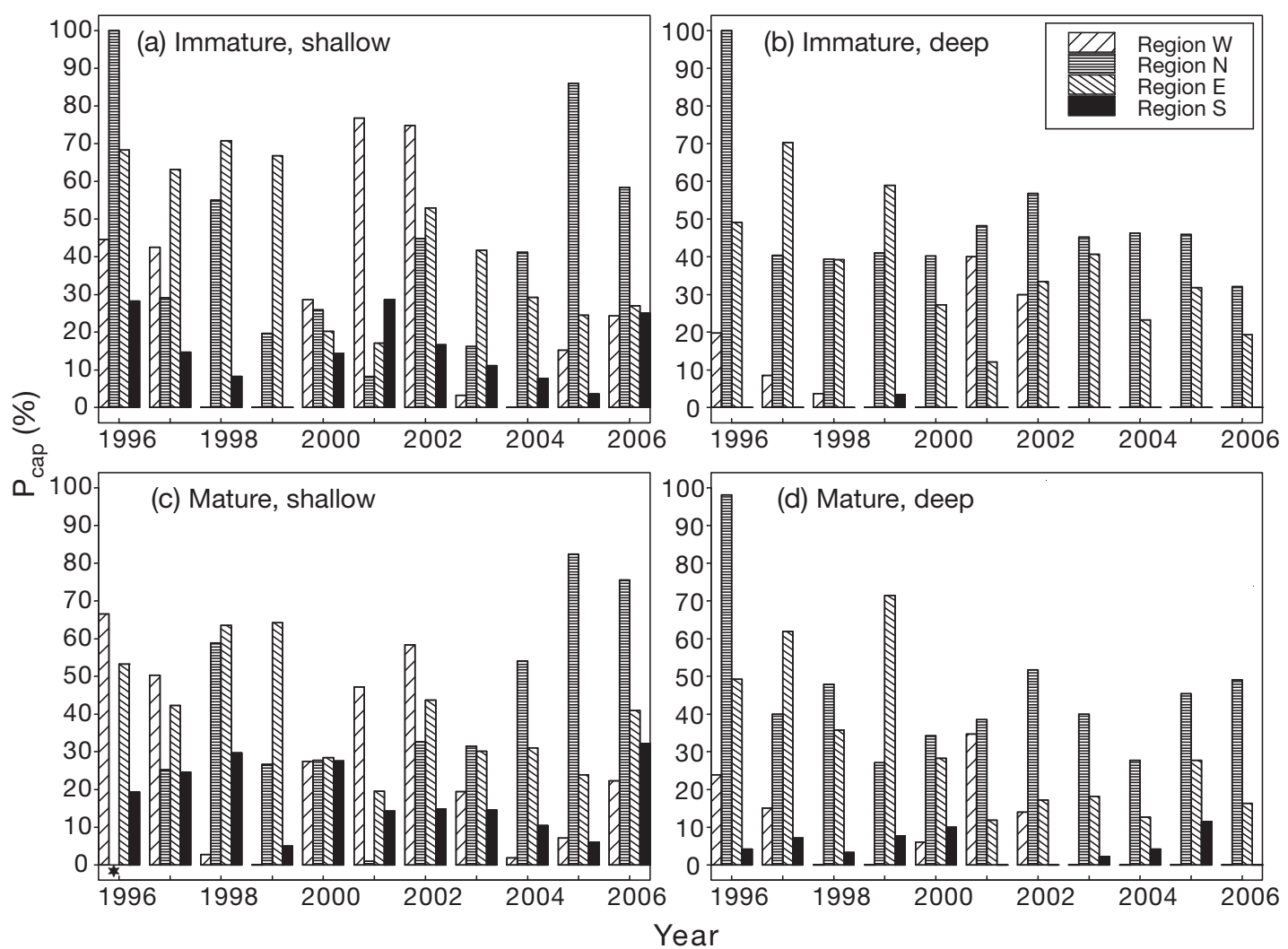

Fig. 5. Gadus morhua. Time series (1996 to 2006) of average proportion of capelin ( $\left.\mathrm{P}_{\text {cap }}\right)$ in stomachs of immature Icelandic cod in (a) shallow $(<200 \mathrm{~m}$ ) and (b) deep $(>200 \mathrm{~m})$ water, and mature Icelandic cod in (c) shallow and (d) deep water in 4 regions (W, N, E and S) of the Icelandic shelf. ${ }^{*}$ Missing data for 1996 (c) 
Table 2. Gadus morhua. Regression equations for significant relationships between the mean annual (1996 to 2006) proportion of capelin in stomachs ( $\left.\mathrm{P}_{\text {cap }}\right)$ and mean annual condition (hepatosomatic index, $\mathrm{H}$ and relative condition factor, $\mathrm{Kr}$ ) of Icelandic cod ( $\mathrm{I}=$ immature, $\mathrm{M}=$ mature $)$ in 2 depth strata $(\mathrm{S}=$ shallow, $<200 \mathrm{~m}$ and $\mathrm{D}=$ deep, $>200 \mathrm{~m}$ )

\begin{tabular}{|c|c|c|c|c|c|c|}
\hline $\begin{array}{l}\text { Condition } \\
\text { index }\end{array}$ & Maturity & Region & Depth & Regression & $\mathrm{r}^{2}$ & $\mathrm{p}$ \\
\hline $\mathrm{H}(\%)$ & I & $\mathrm{N}$ & $\mathrm{S}$ & $\mathrm{H}=2.17+0.05 \times \mathrm{P}_{\text {сар }}$ & 0.68 & $<0.01$ \\
\hline $\mathrm{H}(\%)$ & I & $\mathrm{E}$ & $\mathrm{S}$ & $\mathrm{H}=4.66+0.05 \times \mathrm{P}_{\text {сар }}$ & 0.57 & $<0.01$ \\
\hline $\mathrm{H}(\%)$ & I & $\mathrm{N}$ & $\mathrm{D}$ & $\mathrm{H}=4.14+0.07 \times \mathrm{P}_{\text {сар }}$ & 0.64 & $<0.01$ \\
\hline $\mathrm{H}(\%)$ & M & $\mathrm{N}$ & $\mathrm{S}$ & $\mathrm{H}=4.82+0.02 \times \mathrm{P}_{\text {cap }}$ & 0.40 & 0.05 \\
\hline $\mathrm{H}(\%)$ & M & $\mathrm{N}$ & D & $\mathrm{H}=7.13+0.04 \times \mathrm{P}_{\text {cap }}$ & 0.51 & $<0.05$ \\
\hline $\mathrm{Kr}$ & I & $\mathrm{N}$ & $\mathrm{S}$ & $\mathrm{Kr}=0.95+0.001 \times \mathrm{P}_{\text {cap }}$ & 0.74 & $<0.001$ \\
\hline $\mathrm{Kr}$ & I & $\mathrm{E}$ & $\mathrm{S}$ & $\mathrm{Kr}=0.95+0.001 \times \mathrm{P}_{\text {cap }}$ & 0.71 & $<0.01$ \\
\hline $\mathrm{Kr}$ & I & $\mathrm{E}$ & $\mathrm{D}$ & $\mathrm{Kr}=0.95+0.001 \times \mathrm{P}_{\text {cap }}$ & 0.35 & 0.05 \\
\hline $\mathrm{Kr}$ & M & $\mathrm{N}$ & $\mathrm{S}$ & $\mathrm{Kr}=0.97+0.001 \times \mathrm{P}_{\text {cap }}$ & 0.62 & $<0.01$ \\
\hline $\mathrm{Kr}$ & M & $\mathrm{E}$ & $\mathrm{S}$ & $\mathrm{Kr}=0.98+0.001 \times \mathrm{P}_{\text {cap }}$ & 0.37 & $<0.05$ \\
\hline $\mathrm{Kr}$ & M & $\mathrm{N}$ & $\mathrm{D}$ & $\mathrm{Kr}=0.94+0.001 \times \mathrm{P}_{\text {cap }}$ & 0.52 & $<0.05$ \\
\hline
\end{tabular}

appeared to be most intensive at or near the $200 \mathrm{~m}$ contour line in the northwest and beyond this depth in the north and east. For both immature and mature cod, FI was particularly high in the northwest from 2005-2006, coinciding with a 'good' $\mathrm{P}_{\text {cap }}$ year in region $\mathrm{N}$ as well as a general improvement in Kr after 2003-2004 (Figs. 3, 5 $\& 6)$. Patterns of FI in the east did not clearly follow those observed for condition and $\mathrm{P}_{\text {cap; }}$ it could be interpreted that the number of cod with empty stomachs increased in region E during the time period (Fig. 6), but as with all interpretation of this stomach content data, interannual and spatial variability in the distribution of data points would need to be taken into account $1-83 \%$ and $27-98 \%$, respectively. Similarly, $\mathrm{P}_{\text {cap }}$ of immature cod in shallow and deep water of region $\mathrm{E}$ ranged between $17-71 \%$ and $12-70 \%$, respectively, and $\mathrm{P}_{\text {cap }}$ of mature cod varied between $20-64 \%$ and $12-72 \%$, respectively. Annual mean capelin feeding in region $\mathrm{N}$ was quite stable, with good capelin feeding predominating in the majority of years, particularly in deep water. Overall, $\mathrm{P}_{\text {cap }}$ in the north was lowest from 1999-2001, but was particularly good (>50\%) in 1996 in both depth strata, along with 2005-2006 in shallow water. A general decline in capelin feeding in region $\mathrm{E}$ was observed, perhaps with the exception of mature cod in shallow water. In 1996-1997, $\mathrm{P}_{\text {cap }}$ of immature cod in shallow water was $>63 \%$, and in deep water was $>70 \%$ and $>49 \%$ for immature and mature cod respectively. However, by 2005-2006 $\mathrm{P}_{\text {cap }}$ had fallen to $<27 \%$ for immature cod in shallow water and $<32 \%$ for immature and mature cod in deep water.

Interestingly, significant ( $\mathrm{p} \leq 0.05$ ) positive relationships between mean annual condition ( $\mathrm{H}$ and $\mathrm{Kr}$ ) and mean annual $\mathrm{P}_{\text {cap }}$ of immature and mature cod in shallow $(<200 \mathrm{~m})$ and deep (>200 m) water existed only in regions $\mathrm{N}$ and $\mathrm{E}$ (Table 2 ). Such a relationship was not found between the capelin stock and overall condition of Icelandic cod; all regressions of mean annual condition ( $\mathrm{H}$ and $\mathrm{Kr}$, all regions combined) of age 5 and $6 \mathrm{yr}$ cod and annual adult capelin stock biomass or abundance (for both August of the previous year and January of the same year) were nonsignificant ( $p>0.4$ ).

Analysis of relative capelin biomass in stomachs (FI, $\%$ ) revealed pronounced interannual and spatial variation in capelin consumption by immature and mature cod (Fig. 6). Although unequal sample coverage makes it difficult to make systematic comparisons, it could be concluded that on the whole FI of immature cod was greater than that of mature cod. Feeding on capelin before such a conclusion could be made reliably. Cod feeding on prey species other than capelin did not show any notable spatial or temporal trends.

High densities of cod with empty stomachs or those that had not eaten any capelin (Fig. 6) might explain the relatively poor condition in the west throughout the time series. FI was particularly low in 1998, 1999, 2004 and 2005; Kr of mature 6 yr old cod also reached lowest values in shallow water of region W in 1999, but there were no other distinctive correlations between FI and condition in these years. The peak in condition (Figs. 2 \& 3) and $\mathrm{P}_{\text {cap }}$ (Fig. 5) in region $\mathrm{W}$ in 2001 does correspond to an atypical number of samples with FI > $10 \%$ in depths of $<200 \mathrm{~m}$. However, a similar event occurred in 1997 but $\mathrm{H}$ and $\mathrm{Kr}$ did not improve markedly in this year.

\section{DISCUSSION}

We observed high interannual variability in $\mathrm{H}$ of Icelandic cod, along with variation associated with geographic location, depth and temperature. Surprisingly, $\mathrm{H}$ and $\mathrm{Kr}$ showed very little agreement. Consumption of capelin was found to be related to some of these temporal and spatial trends. In addition, significant relationships between $\mathrm{H}$ and biological characteristics were detected; mature cod were found to be in significantly better condition than immature cod of the same age, and the mean $\mathrm{H}$ of mature females was greater than that of mature males. Conversely, many of these trends were much weaker or not detected by Kr.

Capelin is the most important prey item of Icelandic cod (Magnússon \& Pálsson 1989, 1991), although its contribution by weight to their diet varies between 80 and $90 \%$ during the capelin spawning season in 


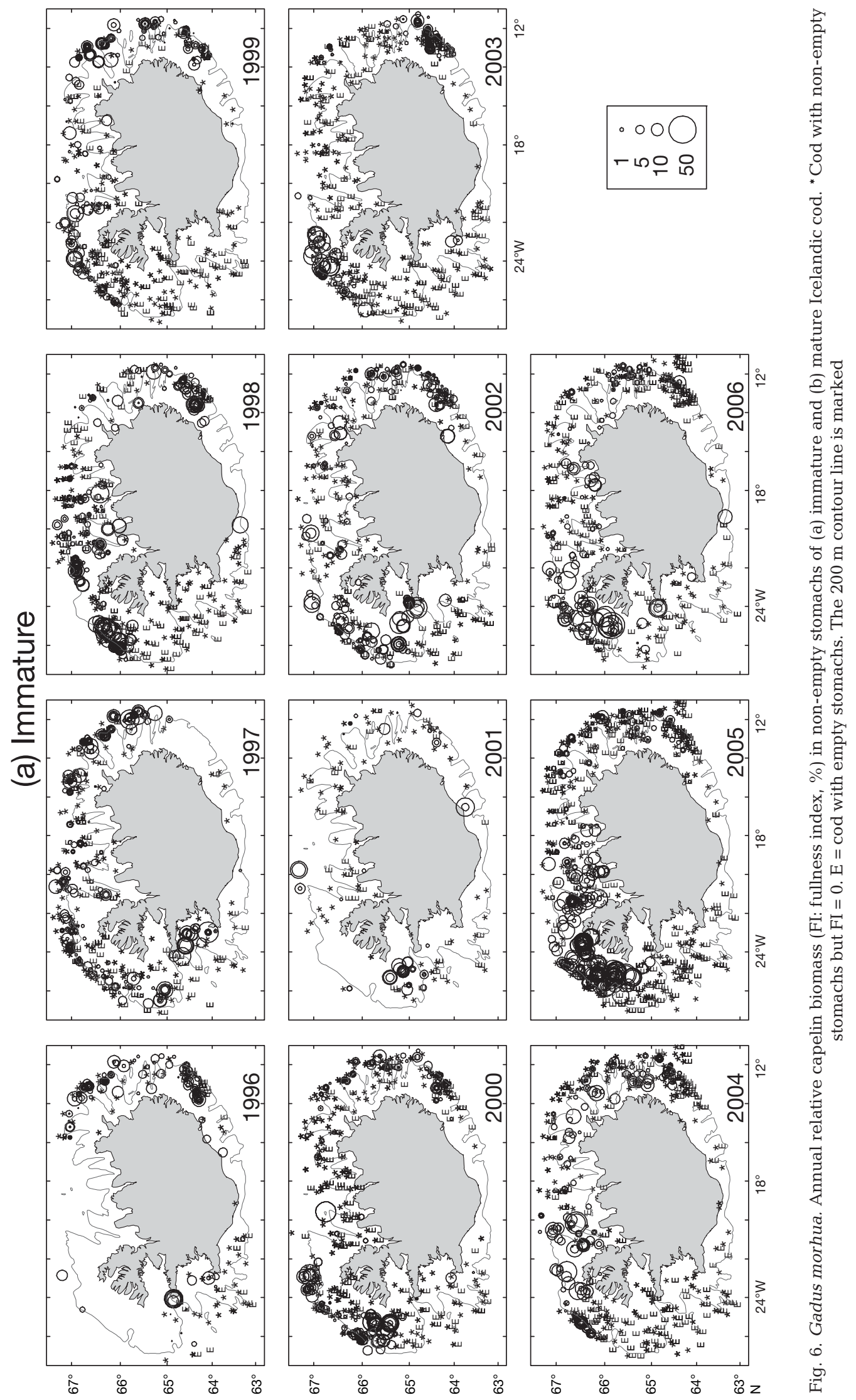



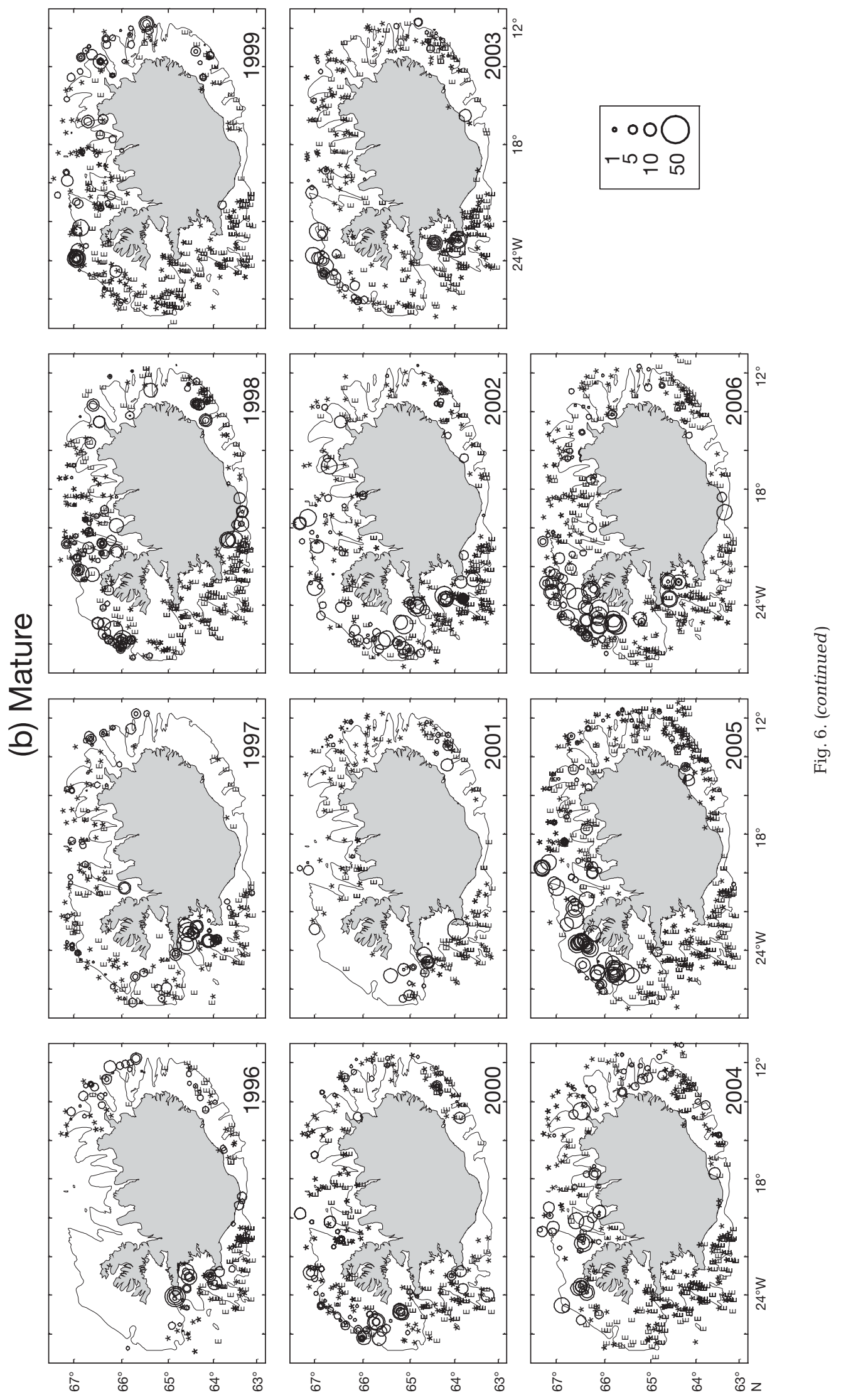
March to $<25 \%$ in summer months (Pálsson 1997). Cod have year-round access to juvenile capelin (ages 0 to $2 \mathrm{yr})$ residing over the shelf off northern Iceland and East Greenland, west of the Denmark Strait (Vilhjálmsson 1994, 2002). Adult capelin (ages 3 and 4 yr) become an available prey item when they return to the vicinity of the shelf break off northwest, north and northeast Iceland in October-November, from feeding grounds in the Iceland Sea and Denmark Strait (Vilhjálmsson 1994, 2002). The capelin spawning migrations begin in December-January and generally follow a clockwise direction along the outer edge of the Icelandic continental shelf to the shallow water spawning grounds off the south and west coasts of Iceland, with peak spawning in March. In some years, however, large spawning migrations arrive on the spawning grounds off west and southwest Iceland directly from the northwest (Vilhjálmsson 1994, 2002).

Metrics of condition are a reflection of nutritional status and $\mathrm{H}$ has been found to be a dynamic index of condition, responding to short-term changes in feeding intensity (Foster et al. 1993, Lambert \& Dutil $1997 \mathrm{a}, \mathrm{b})$. For cod, the major storage location of lipids is the liver whereas most protein is located in the muscle mass (Eliassen \& Vahl 1982a, Holdway \& Beamish 1984, Kjesbu et al. 1991). Jobling et al. (1991) showed that lipid accumulation in the liver of cod is directly related to dietary lipid level and intake. Capelin is an oily fish rich in lipids (Vilhjálmsson 1994) which provides an important biochemical link between capelin and cod (Yaragina \& Marshall 2000). Capelin availability is strongly associated with $\mathrm{H}$ of northern cod off Newfoundland (Rose \& O'Driscoll 2002). In the present study, we found cod in the east and north had the highest mean $\mathrm{H}$. In these regions alone, significant positive relationships were observed between mean annual $\mathrm{H}$ and $\mathrm{Kr}$, and proportion of capelin in cod stomachs $\left(\mathrm{P}_{\text {cap }}\right)$. We also found some agreement between spatial and temporal trends in capelin consumption and condition $(\mathrm{H}$ and $\mathrm{Kr}$ ) of Icelandic cod. Marteinsdóttir \& Björnsson (1999) reported low values of H and Fulton's condition factor $(\mathrm{K})$ in 1998-1999 and that large cod started spawning later, lasting 1 to 4 wk less than in previous years. This was attributed to changes in the distribution and migration of capelin in these years; capelin did not migrate as far west as they had previously. In the present study, such a decline in condition $(\mathrm{H}$ and $\mathrm{Kr})$ was seen in the south and west for some age/maturity groups. Greater relative availability of adult capelin, at least in the short-term (e.g. 3 to 5 mo prior to the March groundfish survey), thus seems to be an important contributing factor to the better condition of cod observed in the northern and eastern regions of the Icelandic shelf.
However, the analyses of stomach content data failed to explain the differences detected in the mean $\mathrm{H}$ of immature and mature cod, and at times only weakly supported the observed temporal and spatial variability, particularly the higher observed $\mathrm{H}$ in deep water. It is therefore important to take into consideration that such data have a number of limitations, such as complications associated with regurgitation and feeding in the net (Bowman 1986), in addition to welldigested contents which cannot be identified and dependence of the results on the number of samples collected (Pinnegar et al. 2003). Therefore, making reliable quantitative and even qualitative deductions from such data appears inherently problematic. Furthermore, such analyses can only provide 'snapshots' of the feeding activity of the predator species in question at particular points in time and space (Pinnegar et al. 2003).

The annual mean liver condition index ( $\mathrm{LCI}_{\text {; }}$ equivalent to $\mathrm{H}$ ) of Northeast Arctic cod decreases rapidly when the biomass of the Barents Sea capelin stock falls below a threshold level (Yaragina \& Marshall 2000). Magnússon \& Pálsson $(1989,1991)$ detected a sigmoid relationship between abundance of the Icelandic capelin stock and consumption of capelin by cod (in March) in 1977 to 1988. Prior to 2002, a significant positive relationship existed between the winter weightat-age of 5 to $8 \mathrm{yr}$ old Icelandic cod and abundance of adult capelin in the summer of the previous year (Vilhjálmsson 2002). Mean weight of cod decreased in the early 1980s and to a lesser extent in the early 1990s, following declines in the capelin stock (Magnússon \& Pálsson 1989, Vilhjálmsson 2002). Mean weights-atage of Icelandic cod are presently near their historical lowest values; for age groups 3 to $7 \mathrm{yr}$, mean weights are estimated to be around $10 \%$ lower than in 2002 (Marine Research Institute 2006). This is thought to be the result of a decline in abundance or availability of capelin on the Icelandic shelf in recent years (Marine Research Institute 2006), potentially due to behavioural changes that have lead to alterations in the distribution of this species (H. Vilhjálmsson pers. comm.).

However, according to our results, this was not reflected by a decline in condition; in the east alone, condition (most notably $\mathrm{H}$ ) was found to have decreased, but this occurred almost consistently throughout the study period of 1993 to 2006. Furthermore, we found no relationship between the size of the capelin stock and average condition ( $\mathrm{H}$ and $\mathrm{Kr}$ ) of the Icelandic cod stock. We speculate that there are a number of factors that could explain these findings: (1) The adult capelin stock size or its availability did not fall below a threshold level which would have lead to a notable decline in condition of the cod stock as a whole. (2) Cod are able to utilise alternative prey, e.g. shrimp (Pan- 
dalus borealis; Magnússon \& Pálsson 1989, 1991), when capelin is scarce so that some level of energy reserves are maintained. However, in regions where capelin is less available, such as the west and south, these reserves, represented by relative liver size, are limited as cod can only partly compensate for the loss of capelin by switching to other foods (Magnússon \& Pálsson 1989, 1991). (3) Cod in the east are more dependent on capelin availability and the observed declining trend in condition is the result of changes in the capelin stock abundance and/or distribution. (4) The spatial variability in both condition and availability of capelin to cod is obscured when considering the stock as a whole, and so biased estimates of condition are obtained. To add further explanation to this last point, it seems intuitive that the extent to which ecological correlations become detectable, in this case between prey abundance and predator condition, will depend on the scale of spatial and/or temporal aggregation considered.

Average $\mathrm{H}$ of Icelandic cod in deep water layers (>200 m) was higher than in shallow layers. This may be linked to lower metabolic costs and/or higher concentrations of food supply within temperature boundaries that the deep-water cod are more likely to enter (Krohn et al. 1997, Pálsson \& Thorsteinsson 2003). However, lower temperatures may also lead to reduced ingestion and assimilation rates (Krohn et al. 1997) and consequently energy accumulation and condition. On the whole, cod in the coolest regions ( $N$ and E) were in better condition, although capelin availability is likely to have made an important contribution to this spatial variation. There were no other apparent overlaps between trends in temperature and condition. Consequently we suggest that temperature, at least that recorded during the spring survey, does not directly determine the condition of Icelandic cod but instead acts as a proxy for other more important factors such as food supply. In support of this, missing or weak temperature effects on condition have been reported in a number of studies. For northern cod, capelin biomass better explained variability in the condition factor whereas temperature explained more variability in growth rates (Krohn et al. 1997). Temperature in the Barents Sea was not consistently correlated with the annual mean $\mathrm{H}$ of Northeast Arctic cod (Yaragina \& Marshall 2000) and no temperature effect on $\mathrm{H}$ or the somatic condition factor was observed during manipulation experiments with Atlantic cod from Scottish waters (Yoneda \& Wright 2005a,b).

However, it is questionable to what extent temperature measurements actually represent the ambient temperature experienced by cod. In addition, many of the mature Icelandic cod that spawn from late March on spawning grounds off the south and southwest coasts will have undertaken a spawning migration to these areas in the months prior to spawning (Jónsson 1996). It is therefore important to remember that the environmental conditions in the locations in which the cod, particularly those that were mature, were caught during the spring groundfish surveys were not necessarily those that had the most influence on their condition. With that in mind, evidence of structure in the Icelandic cod stock is accumulating; recent studies of otolith shape and chemistry and of genetic markers have detected differentiation between cod from the northeastern and southwestern regions and also with depth (Jónsdóttir et al. 2006a,b, Pampoulie et al. 2006, Pétursdóttir et al. 2006). Spawning cod on the northeastern spawning grounds seldom migrate to the southwestern spawning areas and vice versa (Pampoulie et al. 2006). Presence of stock structure is in accordance with the observed higher liver condition in the north relative to the south and west as cod permanently resident in this area are likely to expend less energy in the cooler northern waters where there is greater food availability.

Seasonal variation in condition, related to feeding and reproduction, has been found in a number of cod stocks (e.g. Eliassen \& Vahl 1982b, Lambert \& Dutil 1997a, Schwalme \& Chouinard 1999, Mello \& Rose 2005). Condition tends to peak between September and December following the feeding season, with minimum values associated with spawning reached in the spring. The timing of a study relative to this seasonal trend will therefore affect the values that are obtained. In addition, strong seasonal trends could influence observed interannual variation if the timing of data collection relative to this cycle in condition is inconsistent between years. Very little is known about the seasonal cycle in condition of Icelandic cod and so it is difficult to assess what effect this had on our analyses. However, the groundfish survey consistently takes place in March, and although there is likely to be some variation in the commencement of spawning, both temporally and spatially, we do not expect this to have had a significant influence on our observed trends.

Mature Icelandic cod were found to be in significantly better condition than immature cod in terms of the relative size of their livers. Eliassen \& Vahl (1982b) reported that the total energy content of mature cod from northern Norway was consistently greater than that of immature cod. Seasonal changes in total energy content of both groups were mainly the result of alterations in LW, and immature cod seemingly had insufficient energy levels in the summer period to meet the demands of the maturation process. Similarly, ripening female cod from Smith Sound, Newfoundland had significantly higher LW than those that were immature, 
adolescent or nonreproductive (Rideout et al. 2000). The larger livers of mature compared to immature cod may be linked to hepatic synthesis of vitellogenin during ovarian development (Tyler \& Sumpter 1996), so that a relationship between liver condition and maturity is to be expected (Norberg \& Kjesbu 1991) and is likely to be accompanied by an oestrogeninduced rise in $\mathrm{H}$ (Christiansen et al. 1998). Accordingly, $\mathrm{H}$ has been found to be a robust proxy for estimating the maturity status of female Kattegat cod (Vitale et al. 2006), and to be highly correlated with gonad size in mature female northern cod (Rose \& O'Driscoll 2002).

Differentiation between immature and mature Icelandic cod was much weaker for relative body condition. Differences in Fulton's K of immature and prespawning female cod from the northern Gulf of St. Lawrence were also not observed (Lambert \& Dutil 2000). A similar result for male cod from Smith Sound indicated that protein stored in the white muscle does not fuel testes development (Rideout et al. 2000). Gonads consist primarily of protein (Schwalme \& Chouinard 1999) and for Atlantic cod in northern Norway, their growth accounted for only $10 \%$ of the overwinter loss of tissue energy. Furthermore, immature and mature cod showed similar seasonal differences in water and protein content of muscle; thus gonad and gamete development could only partially explain this seasonality (Eliassen \& Vahl 1982a,b). For cod in the southern Gulf of St. Lawrence, 81 to $96 \%$ of the winter depletion in somatic dry matter was used to meet metabolic, rather than gonad maturation, energy requirements (Schwalme \& Chouinard 1999). However, relationships between body condition and the probability of being mature have been found for Atlantic cod (Marteinsdóttir \& Begg 2002, Dutil et al. 2006) and female American plaice (Morgan 2004). Furthermore, Marteinsdóttir \& Begg (2002) reported significant differences in average Fulton's K of mature and immature Icelandic cod, despite great overlap between the 2 groups.

In the present study we found that mature female cod had better liver condition than mature males. Schwalme \& Chouinard (1999) made comparable observations for Atlantic cod in the southern Gulf of St. Lawrence and suggested this may have been the result of earlier male gonad maturation or female hepatic hypertrophy in response to oestrogen secretion by the developing ovary (Ng \& Idler 1983). Differences in sexrelated energy allocation to reproduction may offer a plausible explanation. Such variation in Atlantic cod is discussed by Yoneda \& Wright $(2005 a$, b) and includes size-related investment in reproduction by first-time spawning females, in contrast to male investment which appeared to maximise current reproduction.
Bromley (2000) found greater pre-spawning build-up in Fulton's K by male North Sea plaice (Pleuronectes platessa), and that the subsequent drop in condition during spawning was approximately half that of females, suggesting sex-specific spawning reserve accumulation and utilisation. A further possible explanation is that of increased hunger at the onset of maturation, with higher feeding intensity in maturing female cod.

Metrics such as $\mathrm{H}$ and $\mathrm{Kr}$ are indirect measures of fish condition, assumed to be synonymous with the magnitude of stored energy reserves. If these indices were equivalent and thus interchangeable measures of cod bioenergetic condition, their analysis would yield similar patterns. However, if we had performed this study using only the morphometric condition index $\mathrm{Kr}$, we would have obtained quite different results to those we have reported. Notably, Kr showed opposite bathymetric trends, and much of the spatial and interannual variation in $\mathrm{H}$, along with the observed differences between immature and mature cod, was not reflected by Kr. Moreover, a meaningful relationship between these individual-level metrics was lacking (Fig. 7). This is consistent with conclusions drawn from a comparison of indices of liver and morphometric condition at the stock level by Marshall et al. (2004).

During starvation, cod mobilise their muscle proteins for energy only when their liver lipid reserves are de-

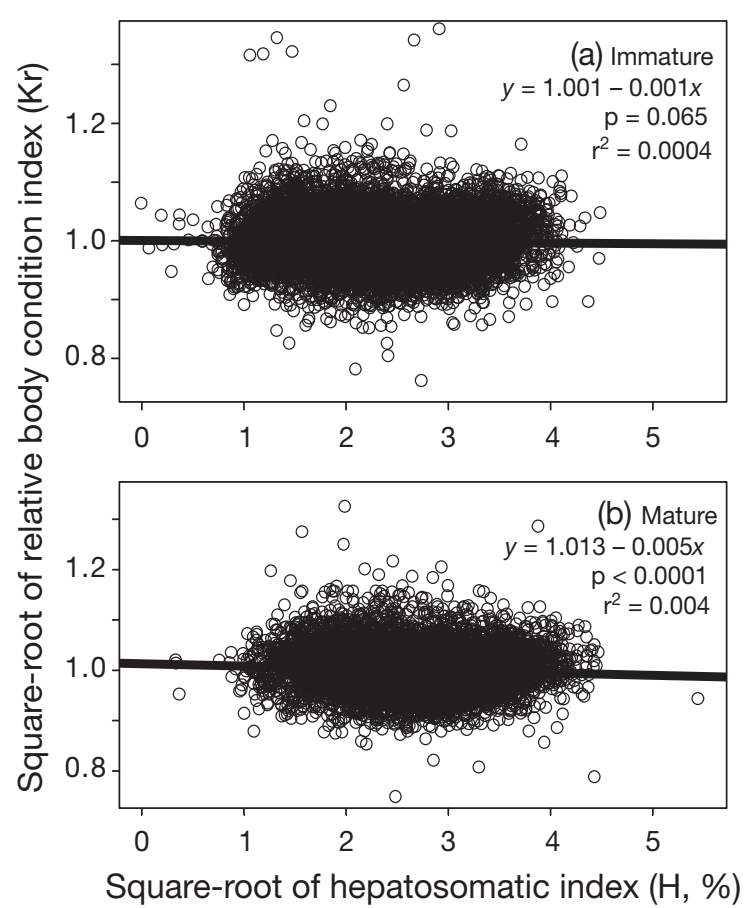

Fig. 7. Gadus morhua. Relationship between hepatosomatic index $(\mathrm{H}, \%)$ and relative body condition index $(\mathrm{Kr})$ of individual (a) immature and (b) mature Icelandic cod from 1993 to 2006 
pleted, probably because proteins have considerably lower energy content than lipids (Holdway \& Beamish 1984, Black \& Love 1986). Lambert \& Dutil (1997b) found good relationships between the muscle and liver energy content of Atlantic cod and Fulton's $\mathrm{K}$ and $\mathrm{H}$ respectively. A large variability in the liver energy content, and therefore $\mathrm{H}$, for a fairly stable range of muscle energy content was observed. $\mathrm{H}$ has been found to be more sensitive to ration than indices of body condition in several species including winter flounder Pseudopleuronectes americanus (Tyler \& Dunn 1976), largemouth bass Micropterus salmoides (Heidinger \& Crawford 1977), minnows Phoxinus phoxinus (Cui \& Wootton 1988) and Atlantic cod (Foster et al. 1993). Consequently, indices based on fish girth are unlikely to respond to alterations in environmental conditions at the same rate as indices based on the relative size of the liver. Classification of $\mathrm{H}$ as a dynamic index of the physiological condition of cod (Yaragina \& Marshall 2000) and as being more proficient at revealing shortterm differences in feeding intensity between, for example, regions and depth strata (Lambert \& Dutil $1997 b$ ) is thus supported by the present study.

Experimentally starved cod generally show $\mathrm{H}<$ $1.5 \%$, although rapid declines in liver energy content are observed when $\mathrm{H}$ falls below 5\% (Lambert \& Dutil 1997a,b, Dutil \& Lambert 2000). Established relationships between condition and factors that influence productivity at both the individual and population level imply that monitoring these simple metrics could be a useful supplementary tool for fisheries management. We found that during the period 1993 to 2006, mature Icelandic cod were generally in good condition in terms of the mean annual relative size of their livers in March. However, our analyses revealed that condition can have a significant spatial component. Taking this spatial variability into account is therefore particularly important for stocks such as Icelandic cod which have to deal with frequently heterogeneous environmental conditions. To achieve this, it is also necessary to identify both the most informative index of condition, and the most appropriate spatial resolution, for the fish stock in question.

Acknowledgements. We thank L. Taylor, A. Vainikka, K. Enberg, C. Jørgensen, T. Miethe, H. Björnsson, H. Vilhjálmsson, Y. Lambert and M. J. Morgan for valuable input and comments. We are grateful for the improvements made to the paper by anonymous reviewers. We also thank the scientists and crews at the Marine Research Institute who were involved in the sampling and preparation of the data used in this study. This research was supported by the European Marie Curie Research Training Network FishACE (Fisheriesinduced Adaptive Changes in Exploited Stocks), funded through the European Community's Sixth Framework Programme (Contract MRTN-CT-2004-005578). The support of the Marine Research Institute is gratefully acknowledged.

\section{LITERATURE CITED}

Begg GA, Marteinsdóttir G (2003) Spatial partitioning of relative fishing mortality and spawning stock biomass of Icelandic cod. Fish Res 59:343-362

Björnsson B (2002) Effects of anthropogenic feeding on the growth rate, nutritional status and migratory behaviour of free-ranging cod in an Icelandic fjord. ICES J Mar Sci 59: 1248-1255

Black D, Love RM (1986) The sequential mobilisation and restoration of energy reserves in tissues of Atlantic cod during starvation and refeeding. J Comp Physiol B 156: 469-479

$>$ Bowman RE (1986) Effect of regurgitation on stomach content data of marine fisheries. Environ Biol Fishes 16:171-181

> Bromley PJ (2000) Growth, sexual maturation and spawning in central North Sea plaice (Pleuronectes platessa L.), and the generation of maturity ogives from commercial catch data. J Sea Res 44:27-43

Christiansen LB, Pedersen KL, Korsgaard B, Bjerregaard P (1998) Estrogenicity of xenobiotics in rainbow trout (Oncorhyncus mykiss) using in vivo synthesis of vitellogenin as a biomarker. Mar Environ Res 46:137-140

Cui Y, Wootton RJ (1988) Effects of ration, temperature and body size on the body composition, energy content and condition of the minnow, Phoxinus phoxinus (L.). J Fish Biol 32:749-764

Dutil JD, Lambert Y (2000) Natural mortality from poor condition in Atlantic cod (Gadus morhua). Can J Fish Aquat Sci 57:826-836

> Dutil JD, Godbout G, Blier PU, Groman D (2006) The effect of energetic condition on growth dynamics and health of Atlantic cod (Gadus morhua). J Appl Ichthyol 22:138-144

Eliassen JE, Vahl O (1982a) Seasonal variations in the gonad size and the protein and water content of cod, Gadus morhua (L.), muscle from northern Norway. J Fish Biol 20: $527-533$

> Eliassen JE, Vahl O (1982b) Seasonal variations in biochemical composition and energy content of liver, gonad and muscle of mature and immature cod, Gadus morhua (L.) from Balsfjorden, northern Norway. J Fish Biol 20: $707-716$

Foster AR, Houlihan DF, Hall SJ (1993) Effects of nutritional regime on correlates of growth rate in juvenile Atlantic cod (Gadus morhua): comparison of morphological and biochemical measurements. Can J Fish Aquat Sci 50: $502-512$

Gudmundsdóttir A, Steinarsson BÆ (1997) An attempt to model the length-weight relationship for saithe in Icelandic waters. ICES CM 1997/CC:08

Heidinger RC, Crawford SD (1977) Effect of temperature and feeding rate on the liver-somatic index of the largemouth bass, Micropterus salmoides. J Fish Res Board Can 34: 633-638

> Henderson BA, Morgan GE (2002) Maturation of walleye by age, size and surplus energy. J Fish Biol 61:999-1011

$>$ Holdway DA, Beamish FWH (1984) Specific growth rate and proximate body composition of Atlantic cod (Gadus morhua L.). J Exp Mar Biol Ecol 81:147-170

Jobling M, Knudsen R, Pedersen PS, Dos Santos J (1991) Effects of dietary composition and energy content on the nutritional energetics of cod, Gadus morhua. Aquaculture 92:243-257

> Jónsdóttir IG, Campana SE, Marteinsdóttir G (2006a) Otolith shape and temporal stability of spawning groups of Icelandic cod (Gadus morhua L.). ICES J Mar Sci 63: 1501-1512 
Jónsdóttir IG, Campana SE, Marteinsdóttir G (2006b) Stock structure of Icelandic cod Gadus morhua L. based on otolith chemistry. J Fish Biol 69(Suppl C):136-150

Jónsson J (1996) Tagging of cod (Gadus morhua) in Icelandic waters 1948-1986 and tagging of haddock (Gadus aeglefinus) in Icelandic waters 1953-1965. Rit Fiskid 14: $1-108$

Kjesbu OS, Klungsøyr J, Kryvi H, Witthames PR, Greer Walker M (1991) Fecundity, atresia, and egg size of captive Atlantic cod (Gadus morhua) in relation to proximate body composition. Can J Fish Aquat Sci 48:2333-2343

Koops MA, Hutchings JA, McIntyre TM (2004) Testing hypotheses about fecundity, body size and maternal condition in fishes. Fish Fish 5:120-130

Krohn M, Reidy S, Kerr S (1997) Bioenergetic analysis of the effects of temperature and prey availability on growth and condition of northern cod (Gadus morhua). Can J Fish Aquat Sci 54:113-121

Lambert Y, Dutil JD (1997a) Condition and energy reserves of Atlantic cod (Gadus morhua) during the collapse of the northern Gulf of St. Lawrence stock. Can J Fish Aquat Sci 54:2388-2400

Lambert Y, Dutil JD (1997b) Can simple condition indices be used to monitor and quantify seasonal changes in the energy reserves of Atlantic cod (Gadus morhua)? Can J Fish Aquat Sci 54:104-112

> Lambert Y, Dutil JD (2000) Energetic consequences of reproduction in Atlantic cod (Gadus morhua) in relation to spawning level of somatic energy reserves. Can J Fish Aquat Sci 57:815-825

Le Cren ED (1951) The length-weight relationship and seasonal cycle in gonad weight and condition in the perch Perca fluviatilis. J Anim Ecol 20:201-219

Lloret J, Rätz HJ (2000) Condition of cod (Gadus morhua) off Greenland during 1982-1998. Fish Res 48:79-86

Magnússon KG, Pálsson ÓK (1989) Trophic ecological relationships of Icelandic cod. Rapp Cons Int Explor Mer 188: 206-224

Magnússon KG, Pálsson ÓK (1991) Predator-prey interactions of cod and capelin in Icelandic waters. ICES Mar Sci Symp 193:153-170

Marine Research Institute (2006) State of marine stocks in Icelandic waters 2005/2006. Prospects for the quota year 2006/2007. Hafrannsóknastofnunin (Marine Research Institute), Reykjavik

> Marshall CT, Yaragina NA, Lambert Y, Kjesbu O (1999) Total lipid energy as a proxy for total egg production by fish stocks. Nature 402:288-290

Marshall CT, Yaragina NA, Ådlandsvik B, Dolgov AV (2000) Reconstructing the stock-recruit relationship for Northeast Arctic cod using a bioenergetic index of reproductive potential. Can J Fish Aquat Sci 57:2433-2442

Marshall CT, Needle CL, Yaragina NA, Ajiad AM, Gusev E (2004) Deriving condition indices from standard fisheries databases and evaluating their sensitivity to variation in stored energy reserves. Can J Fish Aquat Sci 61: 1900-1917

Marteinsdóttir G, Begg GA (2002) Essential relationships incorporating the influence of age, size and condition on variables required for estimation of reproductive potential in Atlantic cod Gadus morhua. Mar Ecol Prog Ser 235: 235-256

Marteinsdóttir G, Björnsson H (1999) Time and duration of spawning cod in Icelandic waters. ICES CM 1999/Y:34

Marteinsdóttir G, Steinarsson A (1998) Maternal influence on the size and viability of Iceland cod Gadus morhua eggs and larvae. J Fish Biol 52:1241-1258
McIntyre TM, Hutchings JA (2003) Small-scale temporal and spatial variation in Atlantic cod (Gadus morhua) life history. Can J Fish Aquat Sci 60:1111-1121

> Mello LGS, Rose GA (2005) Seasonal cycles in weight and condition in Atlantic cod (Gadus morhua L.) in relation to fisheries. ICES J Mar Sci 62:1006-1015

> Morgan MJ (2004) The relationship between fish condition and the probability of being mature in American plaice (Hippoglossoides platessoides). ICES J Mar Sci 61:64-70

$\mathrm{Ng}$ TB, Idler DR (1983) Yolk formation and differentiation in teleost fishes. In: Hoar WS, Randall DJ, Donaldson EM (eds) Fish physiology, Vol 9. Academic Press, New York, p 373-404

Norberg B, Kjesbu OS (1991) Reproduction in coldwater marine fish: applications in aquaculture. In: Scott AP, Sumpter DE, Kime DE, Rolfe MS (eds) Reproductive physiology of fish. FishSymp 91, Sheffield, p 239-243

Pálsson ÓK (1997) Food and feeding of cod (Gadus morhua). In: Jakobsson J, Pálsson ÓK (eds) Fjölstofnarannsóknir (Multispecies research) 1992-1995. Technical report 57. Hafrannsóknastofnunin (Marine Research Institute), Reykjavik, p 177-191 (in Icelandic)

Pálsson ÓK, Björnsson H (1993) Spatial distributions of stomach content data of Icelandic cod. ICES 1993/CCC Symp/ $33 p$

Pálsson ÓK, Thorsteinsson V (2003) Migration patterns, ambient temperature, and growth of Icelandic cod (Gadus morhua): evidence from storage tag data. Can J Fish Aquat Sci 60:1409-1423

Pálsson ÓK, Jónsson E, Schopka SA, Stefánsson G, Steinarsson BÆ (1989) Icelandic groundfish survey data used to improve precision in stock assessments. J Northwest Atl Fish Sci 9:53-72

Pampoulie C, Ruzzante DE, Chosson V, Jörundsdóttir TD and others (2006) The genetic structure of Atlantic cod (Gadus morhua) around Iceland: insight from microsatellites, the Pan I locus, and tagging experiments. Can J Fish Aquat Sci 63:2660-2674

> Pétursdóttir G, Begg GA, Marteinsdóttir G (2006) Discrimination between Icelandic cod (Gadus morhua L.) populations from adjacent spawning areas based on otolith growth and shape. Fish Res 80:182-189

Pinnegar JK, Trenkel VM, Tidd AN, Dawson WA, Du Buit MH (2003) Does diet in Celtic Sea fishes reflect prey availability? J Fish Biol 63:197-212

Powles P (1958) Studies of reproduction and feeding of Atlantic cod (Gadus callarias L.) in the southwestern Gulf of St Lawrence. J Fish Res Board Can 15:1383-1402

Rakitin A, Ferguson MM, Trippel EA (1999) Sperm competition and fertilization success in Atlantic cod (Gadus morhua): effect of sire size and condition factor on gamete quality. Can J Fish Aquat Sci 56:2315-2323

Rätz HJ, Lloret J (2003) Variation in fish condition between Atlantic cod (Gadus morhua) stocks, the effect on their productivity and management implications. Fish Res 60: 369-380

> Rideout RM, Burton MPM, Rose GA (2000) Observations on mass atresia and skipped spawning in northern Atlantic cod, from Smith Sound, Newfoundland. J Fish Biol 57: $1429-1440$

> Rose GA, O'Driscoll RL (2002) Capelin are good for cod: can the northern stock rebuild without them? ICES J Mar Sci 59:1018-1026

- Schwalme K, Chouinard GA (1999) Seasonal dynamics in feeding, organ weights, and reproductive maturation of Atlantic cod (Gadus morhua) in the southern Gulf of St Lawrence. ICES J Mar Sci 56:303-319 
Sparre P, Venema SC (1998) Introduction to tropical fish stock assessment. FAO Fish Tech Pap 306/1 Rev. 2. FAO, Rome

Stefánsson G, Pálsson ÓK (1997) Statistical evaluation and modelling of the stomach contents of Icelandic cod (Gadus morhua). Can J Fish Aquat Sci 54:169-181

Swartzman G, Silverman E, Williamson N (1995) Relating trends in walleye pollock (Theragra chalcogramma) abundance in the Bering Sea to environmental factors. Can J Fish Aquat Sci 52:369-380

Tyler P, Dunn RJ (1976) Ration, growth and measures of somatic and organ condition in relation to meal frequency in winter flounder, Pseudopleuronectes americanus, with hypotheses regarding population homeostasis. J Fish Res Board Can 33:63-75

Tyler CR, Sumpter JP (1996) Oocyte growth and development in teleosts. Rev Fish Biol Fish 6:287-318

Vilhjálmsson H (1994) The Icelandic capelin stock: capelin, Mallotus villosus (Müller) in the Iceland-Greenland-Jan Mayen area. Rit Fiskid 13:1-281

Vilhjálmsson H (2002) Capelin (Mallotus villosus) in the Iceland-East Greenland-Jan Mayen ecosystem. ICES J Mar Sci 59:870-883
Vitale F, Svedäng H, Cardinale M (2006) Histological analysis invalidates macroscopically determined maturity ogives of the Kattegat cod (Gadus morhua) and suggests new proxies for estimating maturity status of individual fish. ICES J Mar Sci 63:485-492

Yaragina NA, Marshall CT (2000) Trophic influences on interannual and seasonal variation in the liver condition index of Northeast Arctic cod (Gadus morhua). ICES J Mar Sci $57: 42-55$

Yoneda M, Wright PJ (2004) Temporal and spatial variation in reproductive investment of Atlantic cod Gadus morhua in the northern North Sea and Scottish west coast. Mar Ecol Prog Ser 276:237-248

> Yoneda M, Wright PJ (2005a) Effect of temperature and food availability on reproductive investment of first-time spawning male Atlantic cod, Gadus morhua. ICES J Mar Sci 62:1387-1393

Yoneda M, Wright PJ (2005b) Effects of varying temperature and food availability on growth and reproduction in firsttime spawning female Atlantic cod. J Fish Biol 67: $1225-1241$

Appendix 1. Gadus morhua. Number of (a) immature and (b) mature Icelandic cod included in analyses by year (1993-2006), age (5-6 yr) statistical region (W, N, E and S) and depth strata (S: shallow, <200m; D: deep, $>200 \mathrm{~m}$ )

\begin{tabular}{|c|c|c|c|c|c|c|c|c|c|c|c|c|c|c|c|c|c|c|c|c|c|c|c|c|c|c|c|c|c|}
\hline \multirow[t]{2}{*}{ (a) } & \multicolumn{2}{|c|}{1993} & \multicolumn{2}{|c|}{1994} & \multicolumn{2}{|c|}{1995} & \multicolumn{2}{|c|}{1996} & \multicolumn{2}{|c|}{1997} & \multicolumn{2}{|c|}{1998} & \multicolumn{2}{|c|}{1999} & \multicolumn{2}{|c|}{2000} & \multicolumn{2}{|c|}{2001} & \multicolumn{2}{|c|}{2002} & \multicolumn{2}{|c|}{2003} & \multicolumn{2}{|c|}{2004} & \multicolumn{2}{|c|}{2005} & \multicolumn{2}{|c|}{2006} & \multirow[b]{2}{*}{ Total } \\
\hline & 5 & 6 & 5 & 6 & 5 & 6 & 5 & 6 & 5 & 6 & 5 & 6 & 5 & 6 & 5 & 6 & 5 & 6 & 5 & 6 & 5 & 6 & 5 & 6 & 5 & 6 & 5 & 6 & \\
\hline W (S) & 44 & 28 & 35 & 7 & 29 & 19 & 35 & 42 & 88 & 15 & 33 & 41 & 24 & 35 & 59 & 15 & 11 & 28 & 37 & 7 & Tו & 23 & 51 & 16 & 53 & 40 & 10 & 25 & 891 \\
\hline$N(S)$ & 57 & 28 & 95 & 20 & 51 & 45 & 50 & 54 & 114 & 28 & 216 & 97 & 85 & 126 & 190 & 47 & 5 & 33 & 87 & 15 & 93 & 58 & 82 & 51 & 172 & 77 & 43 & 79 & 2098 \\
\hline$E(S)$ & 36 & 33 & 88 & 18 & 107 & 66 & 83 & 58 & 113 & 26 & 161 & 53 & 53 & 59 & 126 & 21 & 10 & 35 & 100 & 6 & 143 & 45 & 110 & 39 & 141 & 49 & 70 & 87 & 1936 \\
\hline$S(S)$ & 4 & 0 & 8 & 2 & 27 & 6 & 9 & 10 & 10 & 2 & 11 & 3 & 3 & 5 & 4 & 5 & 2 & 5 & 13 & 4 & 23 & 6 & 11 & 6 & 17 & 10 & 0 & 9 & 215 \\
\hline W (D) & 8 & 1 & 19 & 3 & 31 & 18 & 25 & 19 & 22 & 9 & 43 & 13 & 28 & 31 & 31 & 10 & 11 & 6 & 71 & 13 & 44 & 19 & 67 & 13 & 44 & 41 & 5 & 16 & 661 \\
\hline$N(D)$ & 60 & 38 & 56 & 4 & 93 & 38 & 105 & 56 & 173 & 63 & 251 & 54 & 51 & 54 & 98 & 28 & 14 & 12 & 73 & 14 & 89 & 39 & 74 & 23 & 95 & 35 & 48 & 61 & 1799 \\
\hline E (D) & 24 & 29 & 79 & 16 & 47 & 44 & 44 & 61 & 84 & 20 & 163 & 54 & 49 & 51 & 152 & 16 & 24 & 23 & 167 & 11 & 137 & 34 & 155 & 60 & 233 & 64 & 54 & 189 & 2084 \\
\hline$S$ (D) & 0 & 0 & 9 & 4 & 23 & 11 & 11 & 3 & 1 & 1 & 14 & 7 & 2 & 13 & 26 & 5 & 3 & 3 & 11 & 2 & 13 & 7 & 16 & 8 & 10 & 7 & 1 & 12 & 223 \\
\hline Total & 233 & 157 & 389 & 74 & 408 & 247 & 362 & 303 & 605 & 164 & 892 & 322 & 295 & 374 & 686 & 147 & 80 & 145 & 559 & 69 & 583 & 231 & 566 & 216 & 765 & 323 & 234 & 478 & 9907 \\
\hline
\end{tabular}

\begin{tabular}{|c|c|c|c|c|c|c|c|c|c|c|c|c|c|c|c|c|c|c|c|c|c|c|c|c|c|c|c|c|c|c|}
\hline \multirow[t]{2}{*}{ (b) } & \multirow{2}{*}{$\begin{array}{l}\text { Region } \\
\text { Strata }\end{array}$} & \multicolumn{2}{|c|}{1993} & \multicolumn{2}{|c|}{1994} & \multicolumn{2}{|c|}{1995} & \multicolumn{2}{|c|}{1996} & \multicolumn{2}{|c|}{1997} & \multicolumn{2}{|c|}{1998} & \multicolumn{2}{|c|}{1999} & \multicolumn{2}{|c|}{2000} & \multicolumn{2}{|c|}{2001} & \multicolumn{2}{|c|}{2002} & \multicolumn{2}{|c|}{2003} & \multicolumn{2}{|c|}{2004} & \multicolumn{2}{|c|}{2005} & \multicolumn{2}{|c|}{2006} & \multirow[b]{2}{*}{ Total } \\
\hline & & 5 & 6 & 5 & 6 & 5 & 6 & 5 & 6 & 5 & 6 & 5 & 6 & 5 & 6 & 5 & 6 & 5 & 6 & 5 & 6 & 5 & 6 & 5 & 6 & 5 & 6 & 5 & 6 & \\
\hline & $W(S)$ & 32 & 39 & 45 & 23 & 28 & 42 & 19 & 36 & 51 & 27 & 37 & 58 & 16 & 86 & 34 & 29 & 9 & 44 & 65 & 42 & 61 & 55 & 57 & 79 & 46 & 56 & 20 & 108 & 1244 \\
\hline & $N(S)$ & 18 & 34 & 45 & 20 & 39 & 48 & 11 & 49 & 36 & 15 & 56 & 74 & 42 & 101 & 64 & 37 & 7 & 57 & 57 & 24 & 19 & 49 & 41 & 41 & 53 & 40 & 29 & 61 & 1167 \\
\hline & $E(S)$ & 10 & 22 & 38 & 22 & 52 & 63 & 13 & 25 & 42 & 23 & 40 & 45 & 6 & 38 & 41 & 19 & 2 & 48 & 30 & 6 & 33 & 49 & 27 & 42 & 55 & 35 & 13 & 73 & 912 \\
\hline & $S(S)$ & 7 & 8 & 24 & 19 & 19 & 14 & 16 & 56 & 10 & 10 & 29 & 49 & 8 & 48 & 8 & 3 & 2 & 12 & 42 & 26 & 33 & 45 & 26 & 44 & 16 & 53 & 1 & 28 & 656 \\
\hline & W (D) & 8 & 6 & 32 & 14 & 36 & 35 & 19 & 31 & 12 & 14 & 37 & 31 & 14 & 60 & 33 & 21 & 11 & 19 & 52 & 26 & 22 & 24 & 50 & 46 & 31 & 48 & 10 & 28 & 770 \\
\hline & $N(D)$ & 18 & 32 & 23 & 5 & 35 & 37 & 15 & 47 & 51 & 28 & 63 & 69 & 6 & 58 & 25 & 25 & 5 & 25 & 30 & 9 & 21 & 23 & 19 & 27 & 48 & 28 & 31 & 89 & 892 \\
\hline & $E(D)$ & 6 & 10 & 22 & 22 & 26 & 27 & 5 & 38 & 16 & 19 & 29 & 50 & 8 & 43 & 27 & 21 & 6 & 33 & 21 & 12 & 18 & 31 & 20 & 58 & 71 & 58 & 7 & 53 & 757 \\
\hline & $S$ (D) & 2 & 7 & 57 & 23 & 74 & 71 & 5 & 50 & 18 & 14 & 25 & 40 & 11 & 60 & 15 & 10 & 7 & 31 & 64 & 32 & 54 & 76 & 26 & 61 & 14 & 57 & 4 & 48 & 956 \\
\hline & Total & 101 & 158 & 286 & 148 & 309 & 337 & 103 & 332 & 236 & 150 & 316 & 416 & 111 & 494 & 247 & 165 & 49 & 269 & 361 & 177 & 261 & 352 & 266 & 398 & 334 & 375 & 115 & 488 & 7354 \\
\hline
\end{tabular}

Editorial responsibility: Otto Kinne, Oldendorf/Luhe, Germany
Submitted: June 20, 2007; Accepted: January 21, 2008

Proofs received from author(s): June 3, 2008 